\title{
Effect of ocean acidification on the early life stages of the blue mussel Mytilus edulis
}

\author{
F. Gazeau ${ }^{1,2}$, J.-P. Gattuso ${ }^{1,2}$, C. Dawber ${ }^{3}$, A. E. Pronker ${ }^{4}$, F. Peene ${ }^{4}$, J. Peene ${ }^{5}$, C. H. R. Heip ${ }^{5,6}$, and \\ J. J. Middelburg 5 , \\ ${ }^{1}$ CNRS-INSU, Laboratoire d'Océanographie de Villefranche (UMR7093), BP 28, 06234 Villefranche-sur-Mer Cedex, France \\ ${ }^{2}$ Univ. Pierre et Marie Curie-Paris 6, Observatoire Océanologique de Villefranche, 06230 Villefranche-sur-Mer Cedex, France \\ ${ }^{3}$ Univ. of Cambridge, Department of Earth Sciences, Cambridge CB2 3EQ, UK \\ ${ }^{4}$ Roem van Yerseke BV, Gr. van Zoelenstraat 35, Postbus 25, 4400AA Yerseke, The Netherlands \\ ${ }^{5}$ Netherlands Institute of Ecology (NIOO-KNAW), Centre for Estuarine and Marine Ecology, \\ Postbus 140, 4400 AC Yerseke, The Netherlands \\ ${ }^{6}$ NIOZ Royal Netherlands Institute for Sea Research, Department of Marine Organic Biogeochemistry, \\ P.O. Box 59, 1790 AB Den Burg (Texel), The Netherlands \\ ${ }^{7}$ Faculty of Geosciences, Utrecht Univ., P.O. Box 80021, 3508 TA Utrecht, The Netherlands
}

Received: 30 March 2010 - Published in Biogeosciences Discuss.: 22 April 2010

Revised: 18 June 2010 - Accepted: 23 June 2010 - Published: 1 July 2010

\begin{abstract}
Several experiments have shown a decrease of growth and calcification of organisms at decreased $\mathrm{pH}$ levels. There is a growing interest to focus on early life stages that are believed to be more sensitive to environmental disturbances such as hypercapnia. Here, we present experimental data, acquired in a commercial hatchery, demonstrating that the growth of planktonic mussel (Mytilus edulis) larvae is significantly affected by a decrease of $\mathrm{pH}$ to a level expected for the end of the century. Even though there was no significant effect of a $0.25-0.34 \mathrm{pH}$ unit decrease on hatching and mortality rates during the first 2 days of development nor during the following 13-day period prior to settlement, final shells were respectively $4.5 \pm 1.3$ and $6.0 \pm 2.3 \%$ smaller at $\mathrm{pH}_{\mathrm{NBS}} \sim 7.8\left(p \mathrm{CO}_{2} \sim 1100-1200 \mu \mathrm{atm}\right)$ than at a control $\mathrm{pH}_{\mathrm{NBS}}$ of $\sim 8.1\left(\mathrm{CO}_{2} \sim 460-640 \mu \mathrm{atm}\right)$. Moreover, a decrease of $12.0 \pm 5.4 \%$ of shell thickness was observed after $15 \mathrm{~d}$ of development. More severe impacts were found with a decrease of $\sim 0.5 \mathrm{pH}_{\mathrm{NBS}}$ unit during the first 2 days of development which could be attributed to a decrease of calcification due to a slight undersaturation of seawater with respect to aragonite. Indeed, important effects on both hatching and D-veliger shell growth were found. Hatching rates were $24 \pm 4 \%$ lower while D-veliger shells were $12.7 \pm 0.9 \%$ smaller at $\mathrm{pH}_{\mathrm{NBS}} \sim 7.6\left(p \mathrm{CO}_{2} \sim 1900 \mu \mathrm{atm}\right)$ than at a con-
\end{abstract}

Correspondence to: F. Gazeau

(f.gazeau@obs-vlfr.fr) trol $\mathrm{pH}_{\mathrm{NBS}}$ of $\sim 8.1\left(p \mathrm{CO}_{2} \sim 540 \mu \mathrm{atm}\right)$. Although these results show that blue mussel larvae are still able to develop a shell in seawater undersaturated with respect to aragonite, the observed decreases of hatching rates and shell growth could lead to a significant decrease of the settlement success. As the environmental conditions considered in this study do not necessarily reflect the natural conditions experienced by this species at the time of spawning, future studies will need to consider the whole larval cycle (from fertilization to settlement) under environmentally relevant conditions in order to investigate the potential ecological and economical losses of a decrease of this species fitness in the field.

\section{Introduction}

The atmospheric partial pressure of $\mathrm{CO}_{2}\left(p \mathrm{CO}_{2}\right)$ will continue to increase with projected values for the end of this century ranging from 500 to $1000 \mu \mathrm{atm}$, depending on the considered $\mathrm{CO}_{2}$ emission scenario (IPCC, 2007). Because about one third of anthropogenic $\mathrm{CO}_{2}$ emissions (from fossil fuel, cement production and land-use changes) has been stored in the oceans since the industrial revolution (Sabine et al., 2004), seawater $\mathrm{pH}$ has already declined by 0.1 unit compared with pre-industrial values (Orr et al., 2005) and it is projected to decrease by another 0.35 unit by the end of the century (Caldeira and Wickett, 2003). Ocean

Published by Copernicus Publications on behalf of the European Geosciences Union. 
acidification may have profound impacts on marine biota. Beside the direct effect of decreasing $\mathrm{pH}$ on the physiology and metabolism of marine organisms through a disruption of inter-cellular transport mechanisms (see Pörtner et al., 2004 for a comprehensive review), calcareous organisms are particularly sensitive due to the decreasing availability of carbonate ions $\left(\mathrm{CO}_{3}^{2-}\right)$ driven by increasing $p \mathrm{CO}_{2}$. Indeed, this generates a decrease of the calcium carbonate saturation state $(\Omega)$ :

$\Omega=\frac{\left[\mathrm{CO}_{3}^{2-}\right]\left[\mathrm{Ca}^{2+}\right]}{K_{\mathrm{sp}}^{\prime}}$,

where $K_{\mathrm{sp}}^{\prime}$ is the stoichiometric solubility product, which is a function of temperature, salinity, pressure and the mineral phase considered (calcite, aragonite or high-magnesian calcite). Cold waters will become undersaturated with respect to aragonite $\left(\Omega_{\text {aragonite }}<1\right)$ in a few decades (Orr et al., 2005). Since the seminal paper of Broecker and Takahashi (1966) reporting a dependency of calcification rates on $\mathrm{CaCO}_{3}$ saturation state, several experimental studies have investigated the effect of a $p \mathrm{CO}_{2}$ increase on the growth of calcifying organisms. Most studies have investigated primary producers (corals, coralline algae and coccolithophores) and have shown a very large range of responses (Feely et al., 2004; Kleypas et al., 2006; Doney et al., 2009).

Among calcifying species, molluscans are very important both in ecological and economical terms. Shellfish are ecosystem engineers governing energy and nutrient flows in coastal ecosystems, providing habitats for many benthic organisms and constituting an important food source for, for instance, birds, crabs, starfishes and fishes (Gutiérrez et al., 2003; Norling and Kautsky, 2007). Moreover, with an average annual increase of $7.7 \%$ over the last 30 years, global shellfish aquaculture production reached 13.1 million tons in 2008 , corresponding to a commercial value of US $\$ 13.1$ billion (FISHSTAT Plus vers. $2.3^{1}$ ). The Pacific oyster (Crassostrea gigas) was the most cultivated species in 2008 with a volume of 6.5 million tons or $9.5 \%$ of the total world aquaculture production while mussel production represented 1.9 million tons (US $\$ 390$ million). A negative impact of ocean acidification on the growth of these species would, therefore, not only have major consequences for coastal biodiversity and ecosystem functioning and services, but will also cause a significant economic loss (Gazeau et al., 2007; Cooley and Doney, 2009).

The bivalve Mytilus edulis is a benthic invertebrate typical of the North Atlantic coast of North America, Europe, and other temperate and polar waters around the world. They live in intertidal areas attached to rocks and other solid substrates. This species reproduces by means of a planktonic larval stage (meroplanktonic species). Eggs are fertilized in the

\footnotetext{
${ }^{1}$ FAO: Fisheries Department, Fisherie Information, Data and Statistics Unit. FISHSTAT Plus: Universal software for fishery statistical time series, Version 2.3, 2000.
}

water column and, thanks to their internal energetic resources (lecithotrophic phase), develop to the ciliated trochophore stage and to the D-shaped veliger (shelled) stage within few days depending on the temperature conditions (Pechenik et al., 1990). These veliger larvae start to feed in the water column and gain weight until they reach the pediveliger phase (after few weeks) during which they try to find a place to settle. Larvae become competent to settle at a shell length of $\sim 260 \mu \mathrm{m}$ but can delay metamorphosis and remain in the planktonic compartment until they reach $\sim 350 \mu \mathrm{m}$ (Sprung, 1984). Once the settling conditions are favourable, metamorphosis occurs, plantigrade larvae attach to the substrate thanks to the secretion of the byssus and start to secrete the adult (dissoconch) shell.

Several studies have focused on the effect of projected $\mathrm{pH}$ levels on the growth of benthic (e.g. Gazeau et al., 2007; Ries et al., 2009) and planktonic (Comeau et al., 2009, 2010a, b) molluscs. Most of these studies have demonstrated a negative effect of ocean acidification on the growth of these organisms although recent experiments (Ries et al., 2009) have suggested a more complicated story with species-specific sensitivities to decreasing $\mathrm{pH}$ levels and positive effects on calcification rates in some cases. Early life stages of calcifying organisms are generally considered to be more sensitive to environmental disturbances (Raven et al., 2005). Moreover, amorphous calcium carbonate and aragonite have been identified as the main $\mathrm{CaCO}_{3}$ mineralization form in molluscs larval stages (Medaković, 2000). Therefore, as aragonite is $50 \%$ more soluble than calcite, these aragonitic larval stages are expected to be more sensitive to ocean acidification than calcitic organisms. Indeed, several recent studies have focused on the effect of ocean acidification on the early development of mollusc species (Kurihara et al., 2007; Ellis et al., 2009; Kurihara et al., 2008; Miller et al., 2009; Parker et al., 2009; Talmage and Gobler, 2009; Watson et al., 2009) and most of them have reported negative impacts of decreasing $\mathrm{pH}$ levels on the growth and development of these organisms. So far, there have been no studies on the effect of ocean acidification on the larval development of the blue mussel (Mytilus edulis), the second most cultivated bivalve species in the world after Crassostrea gigas. Blue mussel aquaculture is very important in The Netherlands and consists almost entirely of bottom-culture, carried out on leased sites in the Wadden Sea and in the Oosterschelde estuary (Smaal, 2002). In the Oosterschelde estuary, mussel beds (both wild and from aquaculture) play a major role in the cycling of nutrients and are able to filter the entire volume of the basin in 4-5 days (Prins and Smaal, 1994). In the last two decades, there has been an overall decline in available mussel seed due to intense fishing strategies that has forced local farmers to initiate the production of spats through hatchery techniques (Pronker et al., 2008). The present study aims to investigate the effects of future ocean $\mathrm{pH}$ levels on the development of Mytilus edulis early larval stages in a commercial hatchery. 


\section{Material and methods}

\subsection{Test animals and experimental conditions}

To investigate the effect of rising atmospheric $\mathrm{CO}_{2}$ on mussel (Mytilus edulis) larvae, experiments were carried out in mesocosms at the commercial hatchery Roem van Yerseke (Yerseke, The Netherlands) between 18 October and 27 November 2007. A group of approximately 150 ripe, bottom-cultured mussels from the Oosterschelde, a tidal inlet, were kept at a constant temperature $\left(10^{\circ} \mathrm{C}\right)$ for about 4 months. These animals originated from a same age-class and were fished in the tidal inlet and cultivated for about 2 years on commercial production plots. Before spawning, mussels (male and female) were cleaned with $1 \mu \mathrm{m}$ filtered seawater and placed in a spawning tank. Mass spawning was initiated by rapidly raising water temperature from $10^{\circ} \mathrm{C}$ to $19^{\circ} \mathrm{C}$. Fertilized eggs were retained on a submerged $30 \mu \mathrm{m}$ sieve. During each experiment (see below), six enclosures were used, each of them containing 1301 of filtered $(1 \mu \mathrm{m})$ seawater from the Oosterschelde. Three enclosures were continuously bubbled with ambient air $\left(p \mathrm{CO}_{2} \sim 380 \mu\right.$ atm $)$ while the three others were bubbled with a mixture of ambient air and pure $\mathrm{CO}_{2}$. The flow rates of $\mathrm{CO}_{2}$ were regulated by means of digital thermal mass-flow controllers in order to reach the desired seawater $\mathrm{pH}$.

\subsection{Bioassay}

In a first experiment (experiment \#1), the effects of a $\mathrm{pH}$ decrease from $\sim 8.1$ (control; $p \mathrm{CO}_{2} \sim 460-640 \mu \mathrm{atm}$ ) to, successively, $\sim 7.8\left(p \mathrm{CO}_{2} \sim 1100-1200 \mu \mathrm{atm}\right)$ and $\sim 7.6$ $\left(p \mathrm{CO}_{2} \sim 1900 \mu \mathrm{atm}\right)$ were investigated during the first two days of development (from eggs to D-shape larvae). After fertilization (see above), embryos $(57.7 \pm 4.9 \mu \mathrm{m}$ of diameter) were counted, divided into 6 groups and transferred to the enclosures ( 3 controls, 3 low $\mathrm{pH}$ ) at a density of approximately 10 embryos $\mathrm{ml}^{-1}$. Embryos were maintained in batch conditions (no feeding, no water flowing) until the population reached the D-veliger stage (initial development of the shell, reached in about 2 days).

In a second experiment (experiment \#2), larvae were exposed to $\mathrm{pH}$ values of $\sim 8.1$ and $\sim 7.8$ during the two weeks development period following the D-veliger stage. Embryos were grown at environmental $\mathrm{pH}(\sim 8.0-8.1)$ during 2 days, then counted and evenly transferred to the 6 enclosures ( 3 controls, 3 low $\mathrm{pH}$ ) at a density of approximately 10 embryos $\mathrm{ml}^{-1}$. Cultivation period lasted for 13 days (day 2 to day 15 of development) until the population reaches the pediveliger stage. Larvae were fed in a continuous flowthrough system with a mixture of Isochrysis sp. (T-Iso, CCAP 927/14) and Chaetoceros muellerii (CCMP 1332) (2:1, based on cell counts) at a concentration of approximately 80000 cells $\mathrm{ml}^{-1}$. From day 4 to the end of the experiment, larvae were fed with a mixture of Isochrysis sp.,
Pavlova lutherii (CCAP 931/1) and Chaetoceros muellerii (2:1:2, based on cell counts) at a concentration of approximately 150000 cells ml$^{-1}$.

\subsection{Sampling and analytical measurements}

At the end of experiment \#1 (day 2) and three times a week during experiment \#2, the enclosures were emptied, cleaned with a mixture of diluted acetic acid and $\mathrm{HCl}$ and rinsed with seawater. Water from the tanks was passed through a $90 \mu \mathrm{m}$ sieve and larvae were concentrated in 21 jars. A sub-sample of $50 \mathrm{ml}$ was fixed in a $5 \%$ neutralized-formalin seawater solution to determine the larval abundance, hatching rates (\% of D-veliger larvae) and size. After sampling during experiment $\# 2$, we made sure that $\mathrm{pH}$ was constant and at the desired $\mathrm{pH}$ level before reintroducing the larvae in the enclosures.

Larval abundance was estimated based on triplicate counting of $500 \mu \mathrm{l}$ sub-samples, under a binocular microscope. Larvae shell length (measured on 100 individuals) was measured (anterior to posterior dimension of the shell parallel to the hinge) under a microscope $(20 \times ; 0.01 \mu \mathrm{m}$ precision in length measurement). Shell thickness was estimated from scanning electron micrograph (SEM) images acquired using the JEOL JSE 820 microscope at Cambridge University. Dried larval shells were mounted onto double sided carbon tape and sectioned using a flat edge needle. Loose organic matter and residual shell were removed with a dry paintbrush. Larval shells were removed using a wet paintbrush, reoriented and remounted onto fresh tape attached to aluminium stubs and gold coated. Shell thickness was determined on 20 individuals of each replicate treatment. Hatching rates were defined as the percentage of "normal" D-shape larvae following the criteria proposed by His et al. (1997), after observation of a minimum of 500 larvae.

During the two experiments, $\mathrm{pH}$, temperature and oxygen concentrations were continuously monitored in each enclosure using Metrohm and Consort electrodes, which were calibrated daily on the N. B. S. scale for $\mathrm{pH}$ ( $\mathrm{pH} 4$ and 7). Salinity was measured at the beginning of each incubation period (3) in each enclosure. Daily measurements of total alkalinity (TA) in the 6 enclosures were performed by Gran electro-titration on $50 \mathrm{ml}$ samples filtered on GF/F membranes. Titrations of TA standard provided by A. G. Dickson (batch 82) were within $0.22 \mu \mathrm{eq} \mathrm{kg} \mathrm{k}^{-1}$ of the nominal value $\left(2334.8 \pm 3.3 \mu \mathrm{eq} \mathrm{kg}^{-1} ; n=5\right) . \quad p \mathrm{CO}_{2}$ was computed from $\mathrm{pH}_{\mathrm{NBS}}$ and TA using the software package $\mathrm{CO}_{2}$ 1.1 (M. Frankignoulle) and the thermodynamic constants of Mehrbach et al. (1973). The solubility products for calcite and aragonite were from Morse et al. (1980).

\subsection{Statistical analysis}

For final shell length (experiment \#1 and \#2) and shell thickness (only experiment \#2), differences between replicates of each treatment as well as between control and low $\mathrm{pH}_{\mathrm{NBS}}$ 
Table 1. Environmental parameters and carbon chemistry of experimental seawater during the course of the different experiments. $p \mathrm{CO}_{2}$ and related carbonate parameters were computed from mean $\mathrm{pH}_{\mathrm{NBS}}$ and total alkalinity during each incubation.

\begin{tabular}{|c|c|c|c|c|c|c|}
\hline & \multicolumn{4}{|c|}{ Experiment \#1: day 0 to day 2} & \multicolumn{2}{|c|}{ Experiment \#2: day 2 to day 15} \\
\hline & Control-1 & Low pH-1 & Control-2 & Low $\mathrm{pH}-2$ & Control & Low $\mathrm{pH}$ \\
\hline \multicolumn{7}{|l|}{ Measured parameters } \\
\hline Temperature $\left({ }^{\circ} \mathrm{C}\right)$ & $16.6 \pm 1$ & $16.7 \pm 0.8$ & $16.5 \pm 1$ & $16.2 \pm 1.2$ & $19.5 \pm 0.3$ & $19.2 \pm 0.4$ \\
\hline Salinity & $32.1 \pm 0.1$ & $31.9 \pm 0.2$ & $32.0 \pm 0.1$ & $32.1 \pm 0.1$ & $31.4 \pm 0.3$ & $31.5 \pm 0.1$ \\
\hline Oxygen ( $\%$ of saturation) & $100 \pm 3$ & $94.7 \pm 2.6$ & $96.4 \pm 2.5$ & $97.6 \pm 0.6$ & $91.3 \pm 6.9$ & $91.8 \pm 4.4$ \\
\hline $\mathrm{pH}_{\mathrm{NBS}}$ & $8.15 \pm 0.01$ & $7.81 \pm 0.01$ & $8.09 \pm 0.01$ & $7.58 \pm 0.01$ & $8.03 \pm 0.03$ & $7.78 \pm 0.05$ \\
\hline Chlorophyll- $a\left(\mu \mathrm{g} \mathrm{1^{-1 }}\right)$ & - & - & - & - & $29.12 \pm 8.87$ & $31.12 \pm 12.55$ \\
\hline Total alkalinity $\left(\mathrm{meq} \mathrm{kg}{ }^{-1}\right.$ ) & $2.486 \pm 0.006$ & $2.483 \pm 0.006$ & $2.436 \pm 0.006$ & $2.437 \pm 0.004$ & $2.402 \pm 0.02$ & $2.403 \pm 0.02$ \\
\hline \multicolumn{7}{|l|}{ Calculated parameters } \\
\hline$p \mathrm{CO}_{2}(\mu \mathrm{atm})$ & 468 & 1124 & 537 & 1929 & 642 & 1213 \\
\hline DIC (mmol kg $\left.{ }^{-1}\right)$ & 2.254 & 2.397 & 2.237 & 2.432 & 2.218 & 2.321 \\
\hline$\left(\mathrm{HCO}_{3}^{-}\right)\left(\mathrm{mmol} \mathrm{kg}^{-1}\right)$ & 2.071 & 2.273 & 2.073 & 2.312 & 2.062 & 2.200 \\
\hline$\left(\mathrm{CO}_{3}^{2-}\right)\left(\mathrm{mmol} \mathrm{kg}^{-1}\right)$ & 0.166 & 0.084 & 0.144 & 0.049 & 0.135 & 0.080 \\
\hline$\Omega_{\text {aragonite }}$ & 2.75 & 1.38 & 2.39 & 0.81 & 2.30 & 1.37 \\
\hline$\Omega_{\text {calcite }}$ & 5.12 & 2.58 & 4.45 & 1.52 & 4.27 & 2.54 \\
\hline
\end{tabular}

treatments were tested using one-way ANOVA after testing for normality (Kolmogorov-Smirnov test). No significant differences were found in any of these parameters between the replicate tanks within each experimental condition. For hatching rates and abundances, as only one value was estimated per replicate, this latter was used to obtain grand means and standard deviations (SD) values for each treatment. Since normality tests could not be applied due to the small sample size, differences of hatching rates between control and low $\mathrm{pH}_{\mathrm{NBS}}$ conditions were tested by means of unpaired Student's t-tests using a Welch correction that does not assume equal variance between the two groups (Graphpad Instat software). For all tests, differences were considered significant at $p<0.05$. In the following section, data are presented as means $\pm \mathrm{SD}$.

\section{Results}

The environmental parameters as well as parameters of the carbonate chemistry are shown in Table 1. During experiment \#1, $\mathrm{pH}_{\mathrm{NBS}}$ was maintained, during the first set of incubations, at $8.15 \pm 0.01$ (Control-1) and $7.81 \pm 0.01$ (Low pH-1) corresponding to $p \mathrm{CO}_{2}$ values of 468 and $1124 \mu \mathrm{atm}$, while during the second set of incubations, larvae were kept at $\mathrm{pH}_{\mathrm{NBS}} 8.09 \pm 0.01$ (Control-2) and 7.58 \pm 0.01 (Low $\mathrm{pH}-2$ ), corresponding to $p \mathrm{CO}_{2}$ values of 537 and $1929 \mu \mathrm{atm}$. During experiment \#2, seawater $\mathrm{pH}_{\mathrm{NBS}}$ was maintained at $8.03 \pm 0.03$ (Control, $p \mathrm{CO}_{2}=642 \mu \mathrm{atm}$ ) and $7.78 \pm 0.05$ (Low $\mathrm{pH}, p \mathrm{CO}_{2}=1213 \mu \mathrm{atm}$ ). Results obtained during these 2 experiments are presented in Figs. 1, 2 and 3.
Data used for these figures as well as experimental abiotic parameters $\left(\mathrm{pH}_{\mathrm{NBS}}\right.$, $\mathrm{TA}$ and temperature) measured at the time of sampling are presented in the Supplement Table 1. In the Oosterschelde tidal inlet (1998-2006, monthly measurements, 5 stations), surface $\mathrm{pH}_{\mathrm{NBS}}$ varied annually between 8.00 and 8.24 , while TA varied between 2.334 and $2.567 \mathrm{meq} \mathrm{kg}^{-1}$ (data not shown). In the fall (that is the time of the experimental period), $\mathrm{pH}_{\mathrm{NBS}}$ and $\mathrm{TA}$ in the tidal inlet were, on average, 8.04 and $2.436 \mathrm{meq} \mathrm{kg}^{-1}$, respectively. Significantly higher $\mathrm{pH}_{\mathrm{NBS}}$ values have been obtained for the control tanks in our experiments due to the continuous bubbling with external air $(\sim 380 \mu \mathrm{atm})$, especially during experiment \#1 that was performed in batch conditions. During experiment \#2, the continuous flow-through system did not allow such an efficient equilibration with air, leading to significantly lower $\mathrm{pH}_{\mathrm{NBS}}$ values $(8.03 \pm 0.03)$, closer to environmental levels. It must be stressed that the $p \mathrm{CO}_{2}$ levels for low- $\mathrm{pH}_{\mathrm{NBS}}$ treatments were slightly outside the range projected for the end of the century (500-1000 $\mu \mathrm{atm})$ and must be considered as extreme conditions. The objective of the experiment was to test the effect of a $\sim 0.3 \mathrm{pH}_{\mathrm{NBS}}$ unit decrease on these organisms and, in that sense, experimental conditions were successfully set up and controlled.

During experiment \#1, a seawater $\mathrm{pH}_{\mathrm{NBS}}$ decrease of 0.34 unit $\left(\mathrm{pH}_{\mathrm{NBS}}=7.81 ; \Omega_{\text {aragonite }}=1.38\right)$ had a significant effect on mussel larvae development (Fig. 1). Although no significant effect was found on hatching rates (unpaired Student's t-test, $p>0.05$ ), the average shell lengths at the end of the 2-day incubation period at $\mathrm{pH}_{\mathrm{NBS}} 7.81$ were significantly lower (ANOVA, $n=100, p<0.001$ ) than at higher 


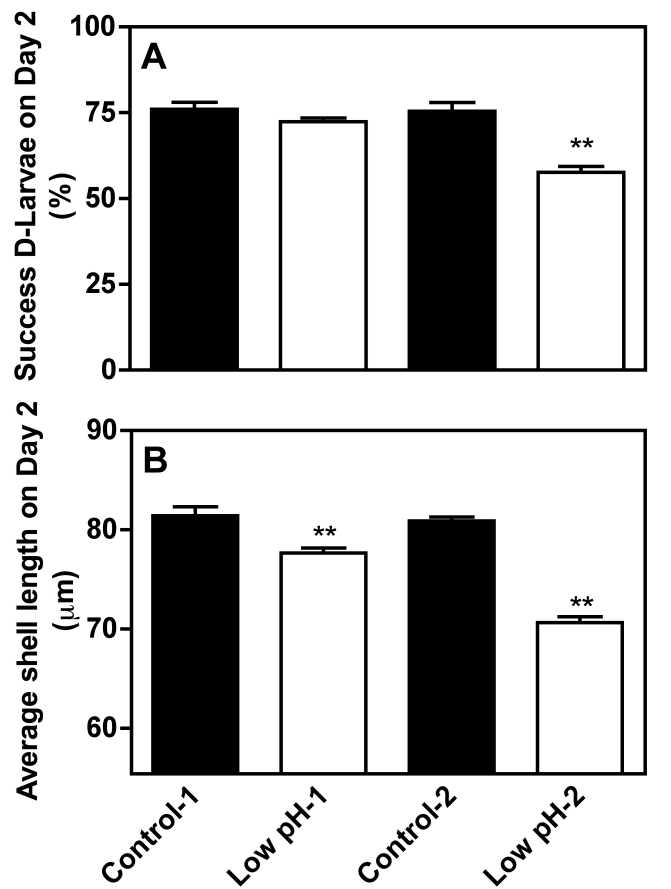

Fig. 1. Proportion of embryos that developed to D-shape larvae (A) and average length of D-shape shell (B) at the end of the two incubation periods during experiment \#1, in control (black bars) and low $\mathrm{pH}$ (white bars) seawater. During the first incubation, seawater $\mathrm{pH}_{\mathrm{NBS}}$ was maintained at $8.15 \pm 0.01$ (Control-1) and at $7.81 \pm 0.01$ (Low $\mathrm{pH}-1$ ). During the second incubation, $\mathrm{pH}_{\mathrm{NBS}}$ levels of $8.09 \pm 0.01$ and $7.58 \pm 0.01$ were used (Control-2 and Low $\mathrm{pH}-2$ respectively). Errors bars represent standard deviations of the triplicate enclosures. $* *$ Significant difference between control and low-pH groups.

$\mathrm{pH}_{\mathrm{NBS}}$. The relative decrease in shell length after 2 days has been estimated to $4.5 \pm 1.3 \%$. In contrast, a decrease of 0.51 unit $\left(\mathrm{pH}_{\mathrm{NBS}}=7.58 ; \Omega_{\text {aragonite }}=0.81\right)$ had large effects on both the hatching and growth rates. The hatching rates decreased by $24 \pm 4 \%$ (unpaired Student's t-test, $p<0.001$ ), while D-veliger shells were $12.7 \pm 0.9 \%$ smaller (ANOVA, $n=100, p<0.001$ ). From day 2 to day 15 (experiment \#2, Figs. 2 and 3), a decrease of seawater $\mathrm{pH}_{\mathrm{NBS}}$ by 0.25 $\left(\mathrm{pH}_{\mathrm{NBS}}=7.78 ; \Omega_{\text {aragonite }}=1.37\right)$ also did not have significant effects on larvae survivorship (unpaired Student's t-test, $n=3, p>0.05$ ) while a significant effect was found for final shell length (ANOVA, $n=100, p<0.001$ ), corresponding to a relative decrease of $6.0 \pm 2.3 \%$. This relative decrease of shell length was statistically significant after day-13 of development. Growth rates, calculated as the difference in shell length between 2 sampling times divided by the time elapsed (d), decreased with increasing shell length (Fig. 2c) under both control and low-pH conditions. Statistically significant linear relationships between growth rates and initial shell length showed a shift to lower growth rates under low-pH conditions which was maintained throughout the experimen-
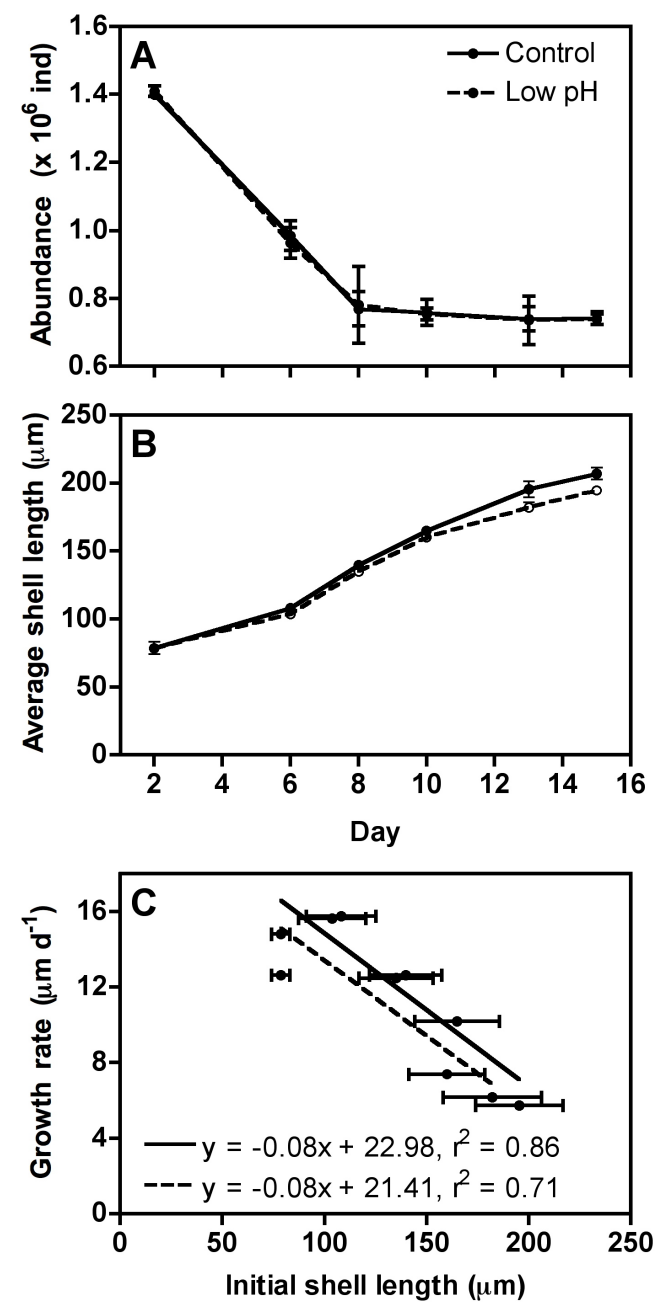

Fig. 2. Abundance (A), average shell length (B) and shell growth rate as a function of initial shell length $(\mathbf{C})$, during experiment \#2 (13 days, from $\mathrm{D}$-shape to pediveliger larvae), in control (solid line, black dots) and $\mathrm{CO}_{2}$ (dotted line, white dots) seawater. Seawater $\mathrm{pH}_{\mathrm{NBS}}$ was maintained at $8.03 \pm 0.03$ and $7.78 \pm 0.05$ in control and low $\mathrm{pH}$ enclosures, respectively. Errors bars represent standard deviations of the triplicate enclosures.

tal period. Effects on final shell thickness (Fig. 3) were more important with a significant (ANOVA, $n=20, p<0.001$ ) relative decrease of $12.0 \pm 5.4 \%$.

\section{Discussion}

In the past few years, several papers have reported on the impacts of seawater acidification on the growth and development of shellfish early life stages. Kurihara et al. (2007, 2008) have demonstrated that a $\mathrm{pH}_{\mathrm{NBS}}$ decrease to $\sim 7.4$ $(-0.7$ as compared to control values) caused a significant alteration of Crassostrea gigas and Mytilus galloprovincialis early (up to $6 \mathrm{~d}$ ) larval development, with significant 


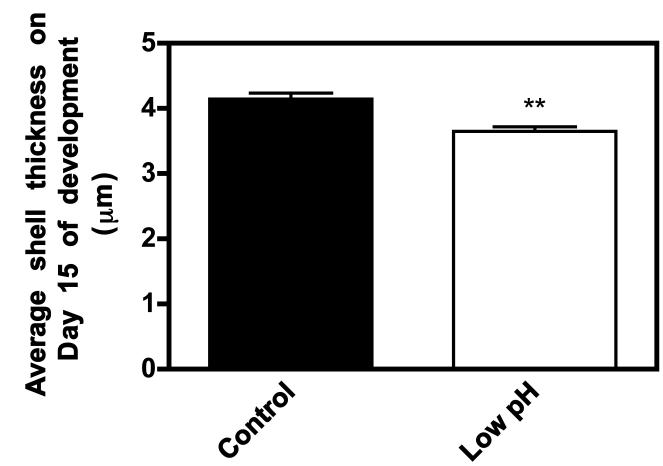

Fig. 3. Average shell thickness at the end of experiment \#2 for larvae on Day 15 of development, in control $\left(\mathrm{pH}_{\mathrm{NBS}}=8.03 \pm 0.03\right.$; black bars) and low $\mathrm{pH}\left(\mathrm{pH}_{\mathrm{NBS}}=7.78 \pm 0.05\right.$; white bars) seawater. Errors bars represent standard deviations of the triplicate enclosures. **Significant difference between control and low-pH groups.

decreases in hatching rates and shell growth. It has to be noted that at this $\mathrm{pH}$ level, which is much lower than the levels projected for the end of the century, the seawater was clearly undersaturated with respect to aragonite $\left(\Omega_{\text {aragonite }} \sim\right.$ 0.68). Parker et al. (2009) studied the synergistic effects of ocean acidification and temperature on the fertilization and early (up to $48 \mathrm{~h}$ ) embryonic development of the Sydney rock oyster (Saccostrea glomerata). These authors found that both fertilization and embryonic development success were diminished at lowered $\mathrm{pH}$ values in the range of projected levels for $2100\left(\mathrm{CO}_{2}\right.$ levels of 600,750 and $\left.1000 \mu \mathrm{atm}\right)$ while temperature revealed an optimal level $\left(26^{\circ} \mathrm{C}\right)$ below and above (i.e. 18,22 and $30^{\circ} \mathrm{C}$ ) which embryonic developmental rates decreased. Talmage and Gobler (2009) performed a multi-species comparison of the effects of ocean acidification on growth and metamorphosis (from 4 to 18 days of development). They actually showed that, although the growth of the 3 studied species (Mercenaria mercenaria, Argopecten irradians, and Crassostrea virginica) was negatively affected, they did not exhibit the same sensitivity to a decrease of up to $0.6 \mathrm{pH}$ unit. This species-specific sensitivity to ocean acidification has also been observed by Miller et al. (2009) who showed that the development (from $96 \mathrm{~h}$ to $\sim 30 \mathrm{~d}$ ) and growth of the Eastern oyster (Crassostrea virginica) was significantly reduced at lowered $\mathrm{pH}$ levels (up to a $0.4 \mathrm{pH}_{\mathrm{NBS}}$ unit decrease), while the Suminoe oyster (Crassostrea ariakensis) did not appear to be sensitive to the same acidified conditions.

In this study, we show that ocean acidification has a significant effect on the blue mussel larval development although the observed decrease in growth rates both in terms of length and thickness was not accompanied by a decrease of hatching rates and an increase in mortality rates as long as seawater remained oversaturated with respect to aragonite. Although no effect on hatching and mortality rates have been observed after $2 \mathrm{~d}$ and after $15 \mathrm{~d}$ of development, the consequences, in the field with the presence of predators, of a potential de- crease of shell resistance and/or an augmentation of the time spent in the water column (delay in settlement) due to a reduction in growth as observed for a $0.25-0.34 \mathrm{pH}$ unit decrease, are still unknown. Since the experimental period did not extend to the settlement and metamorphosis of the organisms, it is impossible to know if the observed decrease in growth rates would translate in a miniaturization of the spats and/or an increase of the time spent in the planktonic compartment. Nevertheless, both effects could have major consequences for the survival of the populations. Suspensionfeeding benthic invertebrates can be important predators of pelagic larvae. In the Oosterschelde estuary, it has been shown that larviphagy from adult bivalves is a major source of mortality for bivalve larvae (Troost et al., 2009). However, several studies showed that, thanks to their shell, larvae could be rejected unharmed with the feces (Mackenzie, 1981). A reduction of the shell both in terms of length and thickness has therefore the potential to increase mortality rates during the planktonic larval stage. Finally, decreases in size during the early developmental stages of marine organisms have been shown to effect juvenile fitness by reducing competitive ability and increasing postsettlement mortality (Anil et al., 2001).

The conditions at which the larvae were exposed in our experiment must be regarded as optimal. In the field, mussels usually spawn in spring when the water temperature is $\sim 8-18^{\circ} \mathrm{C}$ and chlorophyll- $a$ concentrations vary between 0.5 and $19 \mu \mathrm{g} \mathrm{l}^{-1}$ (April-June, 5 stations, monthly measurements; see Table 1 for experimental levels). Therefore, as both experimental parameters were significantly higher than the ones encountered in situ at the time of spawning, the extrapolation, to the field, of our laboratory-based observations on the effects of decreasing $\mathrm{pH}$ on the blue mussel larval development, must be performed with caution. Indeed, Parker et al. (2009) have shown that the effects of ocean acidification on the growth of Sydney rock oyster larvae were greater at sub-optimal temperatures. Moreover, as food availability is a very critical parameter in limiting larval development, the fact that, in the present experiment, food concentrations were optimal could have led to a high resistance of mussel larvae to decreasing $\mathrm{pH}$ levels. The experimental $\mathrm{pH}$ level used for the control incubations in this study also does not reflect the conditions experienced by larvae in situ. Indeed, at the time of spawning, the spring bloom occurring in the Oosterschelde estuary, drives seawater $p \mathrm{CO}_{2}$ to values below atmospheric equilibrium corresponding to an average $\mathrm{pH}$ level of $8.27 \pm 0.09$ (April-June, 5 stations, monthly measurements), a value much higher than the one used as a control during the incubations. In order to evaluate the potential effect of ocean acidification on this species fitness, there is a great need to conduct future experiments under conditions similar to the ones experienced by the organisms in the field.

At $\mathrm{pH}_{\mathrm{NBS}} \sim 7.6$, both hatching success and growth rates (as estimated by shell length decrease after $2 \mathrm{~d}$ of development) exhibited an important decrease coinciding with a 
slight undersaturation of seawater with respect to aragonite. At this point, it can only be speculated that the observed decrease in larval developmental success for a $\sim 0.5 \mathrm{pH}_{\mathrm{NBS}}$ unit decrease is due to the seawater undersaturation with respect to aragonite. It must be stressed that our data do not allow discriminating between the physiological impact of $\mathrm{pH}$ decrease alone via a disruption of inter-cellular transport mechanisms and the impact on calcification resulting from aragonite undersaturation, on the larval development of this species. More studies are needed to disentangle these different aspects of the potential effect of ocean acidification on marine organisms.

As the different pressures exerted by the environment and predators in the field result in a considerable mortality, approaching 99\% (Bayne, 1976) during the free-swimming larval period, an additional $24 \%$ decrease in hatching rates as observed at a $\mathrm{pH}_{\mathrm{NBS}}$ of 7.6 can therefore compromise the survival of the population. Indeed, relatively small fluctuations in the abundance of these larval stages are known to regulate the size of the population (Green et al., 2004). Shellfish predominantly inhabit coastal regions, which usually exhibit lower $\mathrm{pH}$ values than the open ocean because of permanent or episodic low $\mathrm{pH}$ water inputs from rivers (Salisbury et al., 2008), from upwellings (Feely et al., 2008) and due to intense rates of organic matter degradation and/or nitrification (Hofmann et al., 2009). While many estuaries already have high and variable $p \mathrm{CO}_{2}$, atmospheric $\mathrm{CO}_{2}$ enrichment will shift the baseline toward even higher values (Miller et al., 2009) that could lead to extended periods of undersaturation with respect to aragonite, although it has recently been suggested that, in some areas, eutrophication can counter the effects of ocean acidification (Borges and Gypens, 2010). Therefore, these species will most likely be exposed to suboptimal growth conditions in the coming years. In order to assess socio-economic and ecological effects of ocean acidification on shellfish, it is therefore crucial to predict accurately the evolution of $\mathrm{pH}$ as well as the saturation state of the ocean and its coastal waters with respect to aragonite in the near future.

Our observation of no significant effect of a $\sim 0.3 \mathrm{pH}_{\mathrm{NBS}}$ unit decrease on both hatching rates and survivorship stands in contrast with results obtained by Parker et al. (2009) on Saccostrea glomerata during the first $48 \mathrm{~h}$ of development and by Talmage and Gobler (2009) on Mercenaria mercenaria and Argopecten irradians between the veliger and metamorphosed stages (18-20 days). Our results are consistent with those from Talmage and Gobler (2009) on Crassostrea virginica who observed significant effects on growth rates but no significant effects on mortality for a $\sim 0.3 \mathrm{pH}$ unit decrease. Altogether, these different studies reveal, similar to what is observed for adult stages, that the effects of ocean acidification of molluscans early life development are species-specific (Kurihara, 2008) and that the sensitivity of the organisms might depend on the $\mathrm{pH}$ variability at which they are naturally exposed in the field.
It is important to notice that even under aragonite undersaturated conditions, mussel larvae were able to produce a shell, highlighting that molluscs exert a control over calcification (McConnaughey and Gillikin, 2008) and are therefore not completely dependent on environmental conditions. This does not appear as a surprise since most freshwater molluscs are clearly well adapted to such conditions and bivalve growth has been showed by Tunnicliffe et al. (2009) under the extremely undersaturated conditions of deep hydrothermal sites. Most calcifying species, including molluscs, are able to concentrate $\mathrm{Ca}^{2+}$ and $\mathrm{CO}_{3}^{2-}$ ions at the site of calcification. Adult molluscs appear to use conventional calcification physiology by pumping protons from the calcification site (extrapallial fluid), largely through $\mathrm{Ca}^{2+} / 2 \mathrm{H}^{+}$ exchange catalyzed by $\mathrm{Ca}^{2+}$ ATPase (McConnaughey and Gillikin, 2008). The elevation of $\mathrm{pH}$ in the extrapallial fluid (Misogianes and Chasteen, 1979) allows an elevation of the concentration of $\mathrm{CO}_{3}^{2-}$ that favours calcification. However, as this mechanism requires energy, this can lead to substantial energy shifts from other processes and to important costs for the growth of the organism as observed by Wood et al. (2008) for the brittlestar Amphiura filiformis. Although the regulation of calcification by this mechanism is well documented for adults, few studies have focused on the mechanisms of larval calcification and on the capacity of bivalve larvae to regulate calcification rates by controlling the carbonate chemistry at the site of calcification. There is, however, some indication that biomineralization of Mytilus edulis larvae is physiologically controlled, as the activity of the carbonic anhydrase, an enzyme that catalyses the reversible hydration of $\mathrm{CO}_{2}$ to $\mathrm{HCO}_{3}^{-}$and $\mathrm{H}^{+}$, reaches a maximum at the end of each developmental stage connected with biomineralization (Medaković, 2000). This study also reported that these larvae, as showed for other molluscs and echinoderms larvae (Weiss et al., 2002), produce mainly amorphous calcium carbonate during the first 2-3 days of development and aragonite in the following days. As the solubility of amorphous calcium carbonate is 30 greater than that of aragonite (Brečević and Nielsen, 1989), early larval stages should be much more vulnerable than older larval stages and adults that precipitate aragonite and/or calcite. Again, the fact that 2days old larvae were able to produce a shell under aragonite undersaturation highlights the strong regulation capacity of these organisms under sub-optimal growth conditions.

As mentioned previously, in the Oosterschelde estuary, adults are exposed to a relatively narrow range of $\mathrm{pH}$ with winter $\mathrm{pH}$ levels never falling below $\sim 7.9$ and high $\mathrm{pH}$ levels in springtime $(\sim 8.3)$ when spawning and larval development occur. There is, therefore, a great need to evaluate the adaptive capacity of this species to low $\mathrm{pH}$ conditions. This could be achieved by comparing the responses, to a decrease in seawater $\mathrm{pH}$, of populations originating from areas with contrasting environmental conditions with respect to the carbonate chemistry and/or by performing such experiments over several generations. 
Finally, in the present study, we show that shell increase, by linear extension, which is the most commonly measured parameter in ocean acidification related studies for molluscs larvae, should not be the only measured parameter if one wants to investigate the effects of acidification on shell growth. Indeed, shell thickness appeared to be affected as well with a relative decrease twice the relative decrease observed in shell length. This is consistent with Miller et al. (2009) findings who estimated a much higher decrease of shell weight (estimated as the amount of calcium in the shells) than shell area (respectively -42 and $-16 \%$ between pre-industrial and end of 21 st century projected $\mathrm{pH}$ level for C. virginica). However, it must be stressed that, in our study, shell thickness measurements could not be performed on Dveliger ( 2 days old) larvae and appeared to be limited to large pediveliger larvae using our protocol. Calcium content in the shells, as an estimator of shell weight, is also an interesting parameter to follow and has been successfully applied by Miller et al. (2009). However, again, this technique has been applied to large larvae, and there is still a need to test its validity for smaller veliger larvae. Finally, more precise techniques such as ${ }^{45} \mathrm{Ca}$ labelling, recently used on pteropods (planktonic molluscs; Comeau et al., 2009) are promising and might be valuable tools to accurately evaluate the effect of ocean acidification within the range of expected levels for 2100 on calcification rates of mollusc early life stages.

\section{Supplementary material related to this article is available online at: http://www.biogeosciences.net/7/2051/2010/ bg-7-2051-2010-supplement.pdf.}

Acknowledgements. We would like to thank S. Talmage, C. Gobler and two anonymous reviewers for their useful comments and suggestions on our manuscript. This research has received support from the Netherlands Organization of Scientific Research and is a contribution to the "European Project on Ocean Acidification" (EPOCA) which received funding from the European Community's Seventh Framework Programme (FP7/2007-2013) under grant agreement no. 211384.

Edited by: S. Bouillon

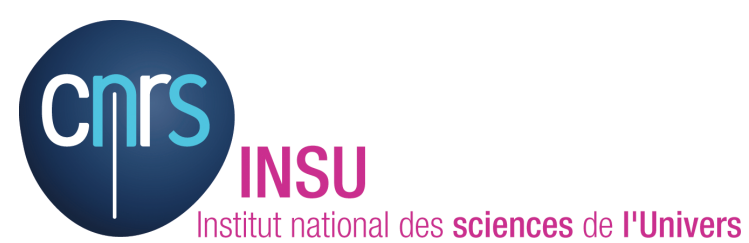

The publication of this article is financed by CNRS-INSU.

\section{References}

Anil, A. C., Desai, D., and Khandeparker, L.: Larval development and metamorphosis in Balanus amphitrite Darwin (Cirripedia; Thoracica): significance of food concentration, temperature and nucleic acids, J. Exp. Mar. Biol. Ecol., 263, 125-141, 2001.

Bayne, B. L.: Marine mussels: their ecology and physiology, International Biological Programme 10, Cambridge University Press, Cambridge, 506 pp., 1976.

Borges, A. V. and Gypens, N.: Carbonate chemistry in the coastal zone responds more strongly to eutrophication than to ocean acidification, Limnol. Oceanogr., 55, 346-353, 2010.

Brečević, L. and Nielsen, A. E.: Solubility of amorphous calcium carbonate, J. Cryst. Growth, 98, 504-510, 1989.

Broecker, W. S. and Takahashi, T.: Calcium carbonate precipitation on the Bahama Banks, J. Geophys. Res., 71, 1575-1602, 1966.

Caldeira, K. and Wickett, M. E.: Anthropogenic carbon and ocean pH, Nature, 425, 365 pp., 2003.

Comeau, S., Gorsky, G., Jeffree, R., Teyssié, J.-L., and Gattuso, J.-P.: Impact of ocean acidification on a key Arctic pelagic mollusc (Limacina helicina), Biogeosciences, 6, 1877-1882, doi:10.5194/bg-6-1877-2009, 2009.

Comeau, S., Jeffree, R., Teyssié, J.-L., and Gattuso, J.-P.: Response of the Arctic pteropod Limacina helicina to projected future environmental conditions, PLoS ONE, 5, e11362, doi:11310.11371/journal.pone.0011362, 2010a.

Comeau, S., Gorsky, G., Alliouane, S., and Gattuso, J.-P.: Larvae of the pteropod Cavolinia inflexa exposed to aragonite undersaturation are viable but shell-less, Mar. Biol., doi:10.1007/s00227010-1493-6, in press, 2010b.

Cooley, S. R. and Doney, S. C.: Anticipating ocean acidification's economic consequences for commercial fisheries, Environ. Res. Lett., 4(8), 024007, doi:10.1088/1748-9326/4/2/024007, 2009.

Doney, S. C., Fabry, V. J., Feely, R. A., and Kleypas, J. A.: Ocean acidification: the other $\mathrm{CO}_{2}$ problem, Ann. Rev. Mar. Sci., 1, 169-192, 2009.

Ellis, R. P., Bersey, J., Rundle, S. D., Hall-Spencer, J. M., and Spicer, J. I.: Subtle but significant effects of $\mathrm{CO}_{2}$ acidified seawater on embryos of the intertidal snail, Littorina obtusata, Aquat. Biol., 5, 41-48, doi:10.3354/ab00118, 2009.

Feely, R. A., Sabine, C. L., Lee, K., Berelson, W., Kleypas, J., Fabry, V. J., and Millero, F. J.: Impact of anthropogenic $\mathrm{CO}_{2}$ on the $\mathrm{CaCO}_{3}$ system in the oceans, Science, 305, 362-366, 2004.

Feely, R. A., Sabine, C. L., Hernandez-Ayon, J. M., Ianson, D., and Hales, B.: Evidence for upwelling of corrosive "acidified" water onto the continental shelf, Science, 320, 1490-1492, 2008.

Gazeau, F., Quiblier, C., Jansen, J. M., Gattuso, J.-P., Middelburg, J. J., and Heip, C. H. R.: Impact of elevated $\mathrm{CO}_{2}$ on shellfish calcification, Geophys. Res. Lett., 34, L07603, doi:10.1029/2006GL028554, 2007.

Green, M. A., Jones, M. E., Boudreau, C. L., Moore, R. L., and Westman, B. A.: Dissolution mortality of juvenile bivalves in coastal marine deposits, Limnol. Oceanogr., 49, 727-734, 2004.

Gutiérrez, J. L., Jones, C. G., Strayer, D. L., and Iribarne, O. O.: Mollusks as ecosystem engineers: the role of shell production in aquatic habitats, Oikos, 101, 79-90, 2003.

His, E., Seaman, M. N. L., and Beiras, R.: A simplification of the bivalve embryogenesis and larval development bioassay method for water quality assessment, Wat. Res., 31, 351-355, 1997. 
Hofmann, A. F., Middelburg, J. J., Soetaert, K., and Meysman, F. J. R.: pH modelling in aquatic systems with time-variable acidbase dissociation constants applied to the turbid, tidal Scheldt estuary, Biogeosciences, 6, 1539-1561, doi:10.5194/bg-6-15392009, 2009.

IPCC: Climate Change 2007: The Physical Science Basis. Contribution of Working Group I to the Fourth Assessment, Report of the Intergovernmental Panel on Climate Change, edited by: Solomon, S., Qin, D., Manning, M., Chen, Z., Marquis, M., Averyt, K. B., Tignor, M., and Miller, H. L., Cambridge University Press, Cambridge, United Kingdom and New York, NY, USA, 996 pp., 2007.

Kleypas, J. A., Feely, R. A., Fabry, V. J., Langdon, C., Sabine, C. L., and Robbins, L. L.: Impacts of ocean acidification on coral reefs and other marine calcifiers: A guide for future research, Report on the workshop held 18-20 April 2005, St. Petersburg, FL, sponsored by NSF, NOAA and the US Geological Survey, 88 pp., 2006.

Kurihara, H., Kato, S. and Ishimatsu, A.: Effects of increased seawater $\mathrm{CO}_{2}$ on early development of the oyster Crassostrea gigas, Aquat. Biol., 1, 91-98, 2007.

Kurihara, $\mathrm{H}$.: Effects of $\mathrm{CO}_{2}$-driven ocean acidification on the early developmental stages of invertebrates, Mar. Ecol. Prog. Ser., 373, 275-284, 10.3354/meps07802, 2008.

Kurihara, H., Asai, T., Kato, S., and Ishimatsu, A.: Effects of elevated $\mathrm{pCO}_{2}$ on early development in the mussel Mytilus galloprovincialis, Aquat. Biol., 4, 225-233, doi:10.3354/ab00109, 2008.

Mackenzie, C. L. J.: Biotic potential and environmental resistance in the American oyster (Crassostrea virginica) in Long Island Sound, Aquaculture, 22, 229-268, 1981.

McConnaughey, T. A. and Gillikin, D. P.: Carbon isotopes in mollusk shell carbonates, Geo-Mar. Lett., 28, 287-299, doi:10.1007/s00367-008-0116-4, 2008.

Medaković, D.: Carbonic anhydrase activity and biomineralization process in embryos, larvae and adult blue mussels Mytilus edulis L., Helgoland Mar. Res., 54, 1-6, 2000.

Mehrbach, C., Culberson, C. H., Hawley, J. E., and Pytkowicz, R. M.: Measurement of the apparent dissociation constants of carbonic acid in seawater at atmospheric pressure, Limnol. Oceanogr., 18, 897-907, 1973.

Miller, A. W., Reynolds, A. C., Sobrino, C., and Riedel, G. F.: Shellfish face uncertain future in high $\mathrm{CO}_{2}$ world: Influence of acidification on oyster larvae calcification and growth in estuaries, PLoS ONE, 4, e5661, doi:10.1371/journal.pone.0005661, 2009.

Misogianes, M. J. and Chasteen, N. D.: Chemical and spectral characterization of the extrapallial fluid of Mytilus edulis, Anal. Biochem., 100, 324-334, 1979.

Morse, J. W., Mucci, A., and Millero, F. S.: The solubility of calcite and aragonite in seawater of $35 \%$ salinity and atmospheric pressure, Geochim. Cosmochim. Acta, 44, 85-94, 1980.

Norling, P. and Kautsky, N.: Structural and functional effects of Mytilus edulis on diversity of associated species and ecosystem functionning, Mar. Ecol. Prog. Ser., 351, 163-175, 2007.

Orr, J. C., Fabry, V. J., Aumont, O., Bopp, L., Doney, S. C., Feely, R. A., Gnanadesikan, A., Gruber, N., Ishida, A., Joos, F., Key, R. M., Lindsay, K., Maier-Reimer, E., Matear, R., Monfray, P., Mouchet, A., Najjar, R. G., Plattner, G. K., Rodgers, K. B.,
Sabine, C. L., Sarmiento, J. L., Schlitzer, R., Slater, R. D., Totterdell, I. J., Weirig, M. F., Yamanaka, Y., and Yool, A.: Anthropogenic ocean acidification over the twenty-first century and its impact on calcifying organisms, Nature, 437, 681-686, 2005.

Parker, L. M., Ross, P. M., and O'Connor, W. A.: The effect of ocean acidification and temperature on the fertilization and embryonic development of the Sydney rock oyster Saccostrea glomerata (Gould 1850), Glob. Change Biol., 15, 2123-2136, doi:10.1111/j.1365-2486.2009.01895.x, 2009.

Pechenik, J. A., Eyster, L. S., Widdows, J., and Bayne, B. L.: The influence of food concentration and temperature on growth and morphological differentiation of blue mussel Mytilus edulis L. larvae, J. Exp. Mar. Biol. Ecol., 136, 47-64, 1990.

Pörtner, H. O., Langenbuch, M., and Reipschlager, A.: Biological impact of elevated ocean $\mathrm{CO}_{2}$ concentrations: Lessons from animal physiology and earth history, J. Oceanogr., 60, 705-718, 2004.

Prins, T. C. and Smaal, A. C.: The role of the blue mussel Mytilus edulis in the cycling of nutrients in the Oosterschelde estuary (The Netherlands), Hydrobiologia, 283, 413-429, 1994.

Pronker, A. E., Nevejan, N. M., Peene, F., Geijsen, P., and Sorgeloos, P.: Hatchery broodstock conditioning of the blue mussel Mytilus edulis (Linnaeus 1758). Part I. Impact of different micro-algae mixtures on broodstock performance, Aquacult. Int., 16, 297-307, doi:10.1007/s10499-007-9143-9, 2008.

Raven, J., Caldeira, K., Elderfield, H., Hoegh-Guldberg, O., Liss, P., Riebesell, U., Shepherd, J., Turley, C., and Watson, A.: Ocean acidification due to increasing atmospheric carbon dioxide. The Royal Society policy document 12/05, The Cloyvedon Press, Cardiff, 58 pp., 2005.

Ries, J. B., Cohen, A. L., and McCorkle, D. C.: Marine calcifiers exhibit mixed responses to $\mathrm{CO}_{2}$-induced ocean acidification, $\mathrm{Ge}$ ology, 37, 1131-1134, doi:10.1130/g30210a.1, 2009.

Sabine, C. L., Feely, R. A., Gruber, N., Key, R. M., Lee, K., Bullister, J. L., Wanninkhof, R., Wong, C. S., Wallace, D. W. R., Tilbrook, B., Millero, F. J., Peng, T. H., Kozyr, A., Ono, T., and Rios, A. F.: The oceanic sink for anthropogenic $\mathrm{CO}_{2}$, Science, 305, 367-371, 2004.

Salisbury, J., Green, M., Hunt, C., and Campbell, J.: Coastal acidification by rivers: a new threat to shellfish?, Eos Trans AGU, 89, 513 pp., 2008.

Smaal, A. C.: European mussel cultivation along the Atlantic coast: production status, problems and perspectives, Hydrobiologia, 484, 89-98, 2002.

Sprung, M.: Physiological energetics of mussel larvae (Mytilus edulis). I. Shell growth and biomass, Mar. Ecol. Prog. Ser., 17, 283-293, 1984.

Talmage, S. C. and Gobler, C. J.: The effects of elevated carbon dioxide concentrations on the metamorphosis, size, and survival of larval hard clams (Mercenaria mercenaria), bay scallops (Argopecten irradians), and Eastern oysters (Crassostrea virginica), Limnol. Oceanogr., 54, 2072-2080, 2009.

Troost, K., Gelderman, E., Kamermans, P., Smaal, A. C., and Wolff, W. J.: Effects of an increasing filter feeder stock on larval abundance in the Oosterschelde estuary (SW Netherlands), J. Sea Res., 61, 153-164, doi:10.1016/j.seares.2008.11.006, 2009.

Tunnicliffe, V., Davies, K. T. A., Butterfield, D. A., Embley, R. W., Rose, J. M., and Chadwick, W. W.: Survival of mussels in extremely acidic waters on a submarine volcano, Nat. Geosci., 2, 
344-348, doi:10.1038/ngeo500, 2009.

Watson, S.-A., Southgate, P. C., Tyler, P. A., and Peck, L. S.: Early larval development of the Sydney Rock oyster Saccostrea glomerata under near-future predictions of $\mathrm{CO}_{2-}$ driven ocean acidification, J. Shellfish Res., 28, 431-437, doi:10.2983/035.028.0302, 2009.
Weiss, I. M., Tuross, N., Addadi, L., and Weiner, S.: Mollusc larval shell formation: Amorphous calcium carbonate is a precursor phase for aragonite, J. Exp. Zool., 293, 478-491, doi:10.1002/jez.90004, 2002.

Wood, H. L., Spicer, J. I., and Widdicombe, S.: Ocean acidification may increase calcification rates, but at a cost, Proc. R. Soc. BBiol. Sci., 275, 1767-1773, doi:10.1098/rspb.2008.0343, 2008. 